\title{
Front Matter: Volume 7888
}

, "Front Matter: Volume 7888," Proc. SPIE 7888, Frontiers in Biological Detection: From Nanosensors to Systems III, 788801 (17 March 2011); doi: 10.1117/12.888791

SPIE. Event: SPIE BiOS, 2011, San Francisco, California, United States 


\title{
PROGRESS IN BIOMEDICAL OPTICS AND IMAGING
}

Vol. 12, No. 6

\section{Frontiers in Biological Detection: From Nanosensors to Systems III}

\author{
Benjamin L. Miller \\ Philippe M. Fauchet \\ Editors
}

22-23 January 2011

San Francisco, California, United States

Sponsored and Published by

SPIE

Volume 7888

Proceedings of SPIE, 1605-7422, v. 7888

SPIE is an international society advancing an interdisciplinary approach to the science and application of light. 
The papers included in this volume were part of the technical conference cited on the cover and title page. Papers were selected and subject to review by the editors and conference program committee. Some conference presentations may not be available for publication. The papers published in these proceedings reflect the work and thoughts of the authors and are published herein as submitted. The publisher is not responsible for the validity of the information or for any outcomes resulting from reliance thereon.

Please use the following format to cite material from this book:

Author(s), "Title of Paper," in Frontiers in Biological Detection: From Nanosensors to Systems III, edited by Benjamin L. Miller, Philippe M. Fauchet, Proceedings of SPIE Vol. 7888 (SPIE, Bellingham, WA, 2011) Article CID Number.

ISSN 1605-7422

ISBN 9780819484253

Published by

SPIE

P.O. Box 10, Bellingham, Washington 98227-0010 USA

Telephone +1 3606763290 (Pacific Time) · Fax +1 3606471445

SPIE.org

Copyright (@ 201 1, Society of Photo-Optical Instrumentation Engineers.

Copying of material in this book for internal or personal use, or for the internal or personal use of specific clients, beyond the fair use provisions granted by the U.S. Copyright Law is authorized by SPIE subject to payment of copying fees. The Transactional Reporting Service base fee for this volume is $\$ 18.00$ per article (or portion thereof), which should be paid directly to the Copyright Clearance Center (CCC), 222 Rosewood Drive, Danvers, MA 01923. Payment may also be made electronically through CCC Online at copyright.com. Other copying for republication, resale, advertising or promotion, or any form of systematic or multiple reproduction of any material in this book is prohibited except with permission in writing from the publisher. The CCC fee code is 1605 $7422 / 11 / \$ 18.00$.

Printed in the United States of America.

Publication of record for individual papers is online in the SPIE Digital Library.

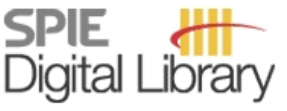

SPIEDigitallibrary.org

Paper Numbering: Proceedings of SPIE follow an e-First publication model, with papers published first online and then in print and on CD-ROM. Papers are published as they are submitted and meet publication criteria. A unique, consistent, permanent citation identifier (CID) number is assigned to each article at the time of the first publication. Utilization of CIDs allows articles to be fully citable as soon they are published online, and connects the same identifier to all online, print, and electronic versions of the publication. SPIE uses a six-digit CID article numbering system in which:

- The first four digits correspond to the SPIE volume number.

- The last two digits indicate publication order within the volume using a Base 36 numbering system employing both numerals and letters. These two-number sets start with 00, 01, 02, 03, 04, $05,06,07,08,09,0 A, 0 B \ldots$. 0Z, followed by 10-1Z, 20-2Z, etc.

The CID number appears on each page of the manuscript. The complete citation is used on the first page, and an abbreviated version on subsequent pages. Numbers in the index correspond to the last two digits of the six-digit CID number. 


\section{Contents}

$\checkmark \quad$ Conference Committee

SESSION I

788802 Silicon photonic microring resonator arrays for scalable and multiplexable bioanalysis (Invited Paper) [7888-01]

M. S. Luchansky, A. L. Washburn, A. J. Qavi, J. T. Kindt, M. S. McClellan, R. C. Bailey, Univ. of Illinois at Urbana-Champaign (United States)

788803 Bioconjugation of ultra-high-Q optical microcavities for label-free sensing [7888-02]

H. K. Hunt, A. M. Armani, The Univ. of Southern California (United States)

788804 Fluorescence enhancement in a polymer-based photonic crystal biosensor [7888-03] B. Hamza, A. Kadiyala, West Virginia Univ. (United States); C. Kilemi, Coppin State Univ. (United States); Y. Liu, J. Dawson, West Virginia Univ. (United States)

788805 Silicon photonic wire evanescent field sensors: sensor arrays and instrumentation (Invited Paper) [7888-04]

S. Janz, A. Densmore, D.-X. Xu, P. Cheben, R. Ma, J. H. Schmid, A. Delâge, M. Vachon,

J. Lapointe, N. Sabourin, W. Sinclair, Y. Li, T. Mischki, G. Lopinski, R. MacKenzie, Q. Liu, E. Post,

B. Lamontagne, National Research Council Canada (Canada); R. Halir,

I. Molina-Fernandez, Univ. de Málaga (Spain)

788807 Molecular detection via hybrid peptide-semiconductor photonic devices [7888-06]

E. Estephan, M. Saab, M. Martin, T. Cloitre, Univ. Montpellier 2, CNRS (France); C. Larroque,

F. J. G. Cuisinier, Univ. Montpellier 1 (France); A. M. Malvezzi, Univ. di Pavia (Italy); C. Gergely, Univ. Montpellier 2, CNRS (France)

788808 Application of ring down measurement approach to micro-cavities for bio-sensing applications [7888-07]

M. Imran Cheema, A. G. Kirk, McGill Univ. (Canada)

7888 OA PMMA-micro goblet resonators for biosensing applications (Invited Paper) [7888-09]

T. Beck, M. Hauser, T. Grossmann, D. Floess, S. Schleede, J. Fischer, C. Vannahme, T. Mappes,

H. Kalt, Karlsruhe Institute of Technology (Germany)

\section{SESSION II}

7888 OD Confocal Raman microscopy for identification of bacterial species in biofilms [7888-12]

B. D. Beier, Univ. of Rochester (United States); R. G. Quivey, Univ. of Rochester Medical Ctr. (United States); A. J. Berger, Univ. of Rochester (United States) 
7888 ol Aqueous arrayed imaging reflectometry as a sensitive plafform for real-time biomolecular interaction analysis [7888-17]

A. R. Yadav, C. R. Mace, B. L. Miller, Univ. of Rochester (United States)

\section{MICROFLUIDIC DEVICES AND SYSTEMS FOR PATHOGEN DETECTION: JOINT SESSION WITH} CONFERENCE 7929

$7888 \mathrm{OL}$ Optical and fluidic design for guaranteed trapping and detection of particles in a silicon microfluidic and photonic crystal system [7888-20]

A. T. Heiniger, Univ. of Rochester (United States); B. L. Miller, Univ. of Rochester Medical Ctr. (United States); P. M. Fauchet, Univ. of Rochester (United States)

7888 OM Towards an optical concentrator for nanoparticles [7888-21]

J. E. Baker, R. Sriram, P. M. Fauchet, B. L. Miller, Univ. of Rochester (United States)

$788800 \quad$ All-fiber optofluidic biosensor [7888-23]

Y. Guo, H. Li, J. Liu, K. Reddy, X. Fan, Univ. of Michigan (United States)

$7888 \mathrm{OP} \quad$ Application of field-modulated birefringence and light scattering to biosensing [7888-24] L. H. Strong, D. B. Hall, C. M. Edson, Radiation Monitoring Devices, Inc. (United States); H. Nguyen, TransMembrane Biosciences, Inc. (United States); M. A. Whitt, The Univ. of Tennessee Health Science Ctr. (United States); G. Varadi, Radiation Monitoring Devices, Inc. (United States)

$7888 \mathrm{OR}$ An integrated microfluidic biosensor for the rapid screening of foodborne pathogens by surface plasmon resonance imaging [7888-26]

M. D. Zordan, M. M. G. Grafton, J. F. Leary, Purdue Univ. (United States)

\section{POSTER SESSION}

7888 OS The radix 4 base number system for use in theoretical genetics [7888-27]

B. S. Tice, Advanced Human Design (United States)

Author Index 


\title{
Conference Committee
}

\author{
Symposium Chairs
}

James G. Fujimoto, Massachusetts Institute of Technology (United States)

R. Rox Anderson, Wellman Center for Photomedicine, Massachusetts General Hospital, Harvard School of Medicine (United States)

Program Track Chair

Brian Jet-Fei Wong, Beckman Laser Institute and Medical Clinic (United States)

Conference Chairs

Benjamin L. Miller, University of Rochester (United States)

Philippe M. Fauchet, University of Rochester (United States)

Program Committee

Holger Becker, microfluidic ChipShop GmbH (Germany)

Xudong Fan, University of Michigan (United States)

Jiri Homola, Institute of Photonics and Electronics of the ASCR, v.v.i. (Czech Republic)

Hongrui Jiang, University of Wisconsin-Madison (United States)

Laura M. Lechuga, Centre d'Investigacions en Nanociència i Nanotecnologia (Spain)

Frances S. Ligler, U.S. Naval Research Laboratory (United States)

Daniel V. Lim, University of South Florida (United States)

Christopher Myatt, Precision Photonics Corporation (United States)

Elric W. Saaski, Research International, Inc. (United States)

Michael J. Sailor, University of California, San Diego (United States)

Christopher C. Striemer, Adarza Biosystems Inc. (United States)

Sharon M. Weiss, Vanderbilt University (United States)

Session Chairs

Session 1

Benjamin L. Miller, University of Rochester Medical Center (United States) 
Session II

Philippe M. Fauchet, University of Rochester (United States)

Microfluidic Devices and Systems for Pathogen Detection: Joint Session with Conference 7929

Benjamin L. Miller, University of Rochester Medical Center (United States) 